\title{
Moving the andragogy of teacher educators forward: the potential and challenges of Problem-Based Learning in teacher education
}

Authors:

Russell Grigg ${ }^{1}$ Helen Lewis ${ }^{2}$

${ }^{1}$ Ministry of Education United Arab Emirates

${ }^{2}$ University of Wales Trinity Saint David

\section{ABSTRACT}

Objectives: To explore the benefits of Problem-Based Learning (PBL) for pre-service trainee teachers, as a preparation for teaching in the primary school.

Methodology: A case study at one centre of teacher education in Wales is reported, using a pragmatic, mixed methods approach. The research tools used included semi-structured interviews, questionnaires, and analysis of videorecorded group meetings and module marks.

Results: Two hundred and eighty students (160 postgraduate and 120 undergraduate) responded to the questionnaire. Almost all report PBL to be highly motivating, engaging and relevant to teacher training. PBL modules had higher average marks for both postgraduate and undergraduate students than non-PBL modules. Interviews and video analysis with a focused group of fourteen students reveal perceived learning gains in applying theoretical knowledge to real-life problems, understanding multiple viewpoints and challenging assumptions. The greatest perceived challenges were self-directed research and time management.

Conclusions: Current discourse around the quality of initial teacher education in the UK focuses on institutional structures, location of training and leadership. We argue that PBL, and the quality of andragogy generally among teacher educators, should feature more strongly in these discussions.

Keywords: Teacher education, Higher education, Problem-based learning, Wales

Address reprint requests to: Dr. Russell Grigg

Ministry of Education United Arab Emirates.

Tel: +07-98-541-1173, E-mail: Grigg.russell@googlemail.com

Dr. Helen Lewis

University of Wales Trinity Saint David.

E-mail: H.e.lewis@uwtsd.ac.uk 


\section{INTRODUCTION}

Over the last decade or so, initial (pre-service) teacher education in the United Kingdom has been in the political spotlight. Government-commissioned reviews have been conducted in England (Carter, 2015), Scotland (Donaldson, 2011), Wales (Furlong, 2015) and Northern Ireland (DEL, 2014). These reviews tackle common themes relating to the respective contribution of educational theory, research and practical experience to the training and education of prospective teachers. Their agenda for improvement has focused largely on structural changes. The most obvious example has been the shift towards more school-based training and a corresponding reduction in university-based input (Universities UK, 2014: 1). Yet it is not structural change that will fundamentally improve the quality of teacher training but the interaction between teacher educators (both in university and school) and their students. Research indicates that teachers in the most successful educational systems employ a range of teaching methodologies (OECD, 2010; Darling-Hammond and Rothman, 2011; Tabberer, 2013).

This paper's central argument therefore is that the 'how' as well as the 'where' and 'what' of initial teacher training should feature more strongly in debates. We describe how Problem-based Learning (PBL) is used to motivate and engage students and staff in higher education. In this paper, PBL is defined as a student-led approach to learning in which real-world educational issues are explored in order to develop content knowledge and higher-order thinking skills. We argue that PBL has the potential to fill the space between theory and practice in the context of teacher education. As Biggs and Tang (2007: 231) explain, PBL reflects the way people learn in real life.'

\section{Purpose of study}

The overall aim of the study was to explore the strengths and challenges associated with PBL in teacher pre-service education, through a case study context. This study makes an important contribution to the area, since although PBL is used increasingly in disciplines such as medicine, natural sciences, dentistry and engineering, there is less evidence on its use within teacher education (Schwartz et al., 2001).

\section{Initial teacher training and education (ITET) in the UK}

Over recent years one of the most discernible trends since in ITET within the UK and further afield has been the shift towards school-based provision, even on programmes led by universities. One aspect that has not been discussed in detail, however, is how teacher educators approach learning and teaching. Recent reviews of initial teacher training in the UK have said very little on the subject other than (in England) the quality of school mentoring is 'not as good as it should be' (Carter, 2015: 59) and (in Scotland) there is a wide variation in the extent to which universities fully equip students to meet the greatest challenges in school (Donaldson, 2011). If such a debate develops, PBL has an important part to play because its theory-into-practice nature is such that, if well implemented, it can equip prospective teachers with the kinds of skills and dispositions that the profession urgently needs.

In Wales, following organisational changes introduced in 2006, ITET is provided through three regional centres, one of which is the context for this research. The need to reform ITET in Wales has been highlighted by both independent inspection reports and governmentcommissioned reviews (Estyn, 2015a; Tabberer, 2013; Furlong, 2015). These reviews have focused on structural 
changes such as the balance between university and school-led input. However, there has been less emphasis upon exploring how pre-service teachers are instructed. This study will be of relevance to those involved in teaching globally, since the need for more effective education systems has been highlighted by variations in students' outcomes, both between and within nations, regions and schools. Teachers are widely recognised as a key determinant in learner outcomes (Hattie, 2013), but they need to learn to work together in 'cooperation and dialogue' to get the best outcomes from learners (Caena, 2014:3). Teachers need to possess core competencies such as sound knowledge of education theories, a deep knowledge of how to teach, interpersonal skills, and the capability to adapt plans and practices to contexts and student needs (European Commission, 2013). This paper takes the position that PBL offers student teachers the opportunity to develop and hone such skills and competencies in an authentic and engaging manner.

\section{Case study context}

PBL was introduced in our teacher training department as a pilot in 2009 following discussions over how to engage students more effectively. Our self-evaluation suggested we needed 'instructional shift' if students were to become more engaged in sessions and equipped with the higherorder thinking skills demanded by the teaching profession. In a few instances, there was a prevailing tendency to 'spoon feed', something that students themselves wanted and appreciated - as one explained, 'if I don't leave the lecture with lots of hand-outs and notes I feel shortchanged. However, if one of the goals of initial teacher training is to create a culture in which reflective, enquiring and critical thinkers can flourish, then research indicates that teachers in the most successful educational systems employ a range of teaching methodologies (OECD, 2010;
Menter et al., 2010; Darling Hammond and Rothman, 2011; Tabberer, 2013). PBL has since developed as one of the core organising principles that underpin our primary undergraduate and postgraduate programmes. Typically, these recruit 120 undergraduates and 160 postgraduate students. For undergraduates, PBL is planned as follows:

- Students form groups of 5-6 and undertake PBL tasks within the core modules. These are structured to reflect their experiences to date, both in schools and within university.

- In Year 1, students are presented on a 'drip feed' basis with an unfolding narrative in which a 'model' trainee faces a series of challenges during his first school placement; for instance, relating to lesson preparation, behaviour management and acting professionally. The students work in groups to consider strategies to address situations and discuss these in seminars with an assigned PBL tutor.

- In Year 2, students respond to case study notes relating to individual pupils with specific learning difficulties and draw upon expertise from a range of specialist visiting speakers who address them as part of the module. The scenarios reflect broad issues such as specific learning difficulties, and strategies to encourage successful engagement with parents.

- In Year 3, the scenario is based on a parent's letter of complaint (figure 1). Students, working in groups, are expected to identify and address these concerns culminating in a meeting with the parent. Students are expected to draw upon their experiences throughout the course - connecting their school-based and university learning.

The scenarios were co-constructed by the PBL module team, which were based on their own first- 
You have received the following letter of complaint from a parent. Read through the letter and identify the most important issues.

Mr Thomas

Headtescher

Rainbow Church School

Birmingham

12 January 2012

\section{Dear Mr Thomas}

I am worried about my children in school. Mikolaj, the young one, comes home unhappy.

He is not doin well. I was disappointed wen I was told by Ms Fresh at parents evening that Mikolaj is not needing homework. Why? he is a good worker. She says that new changes in curriculum mean no nus for lots of writing but more play. I not happy about this. He can play at home in the park. He is always forgetting things and has lats of burnps and brusis fram playing too much in school, he needs sit down to learn to hold pen and write more.

Mikolaj has said to me that he is called names in school. He is not sleeping well at home. He say nothing is done. But I have told him to hit back if need be. Mrs Telltale, our netghbour, has told me at school gates that this the best thing to do in this country.

I hear that children are going an another wisit soon to the form. mikalaj knows lats about farms back home. Why does he need to go? Do I have to pay for this?

My wife and I are not together but she would like to know how children are doing in school. She not hand report on Haitna for last year.

Please can you see me to discuss my worries?

\section{Mr Kowalewski}

Figure 1. An example of a scenario used with third-year student teachers(the letter contains some deliberate spelling errors). hand experiences as teachers in school thus providing necessary authenticity and credibility. The scenarios were anonymised in line with University ethical procedures.

In their PBL, postgraduate students access a virtual school, complete with its own website on which they find real-life scenarios such as emails from parents and 'real-life' data about the school and the performance of its learners. The scenarios are designed with input from senior, school-based mentors and are supported by targeted visits to schools, for example to explore models of parental engagement first-hand. At the start of the module, the students form small groups and undertake their independent research. They are assessed via individual essay, based upon initiatives aimed at improving family and community engagement, and by oral presentation to a panel of 'governors' (which includes a real school governor, university tutor and head teacher) where small groups of students take on the role of a school leadership team in submitting an action plan to address issues arising from the school's core performance data.

A core aspect of the PBL process is the small group (56) tutorial, during which students create and recreate knowledge around real-life problems. The role of the tutor is to facilitate discussion (Barrett, 2004).

\section{CONCEPTUAL FRAMEWORK}

It is not necessary in this article to review in detail the background or theory behind PBL given the extensive literature in the field (Savin-Baden, 2000; Barrett, 2010; Henderson, 2016). Although there are different versions of PBL, most seek to promote reasoning skills, independent and collaborative learning, increase student motivation and applied knowledge i.e. knowledge that students can construct and then put to work. PBL is less concerned with 
'covering' content and does not begin with the teaching of domain or subject-specific knowledge. Rather real-world problems drive the learning and teaching. PBL addresses many of the intended learning outcomes that are common to higher education, including accommodating new knowledge; interrogating assumptions; working effectively with others as part of a team, taking different roles; and identifying, synthesising, evaluating and analysing problems (QAA, 2015).

\section{Learning theories}

PBL draws on a wide range of learning theories, particularly social constructivism and andragogy, which values discussion, collaboration, and the co-creation of knowledge. One of the principles of andragogy is that as people mature they become more self-directed and tend to be less subject-centred and more problem-centred in their approach. Experiential models of learning (Kolb, 1984) where case studies, role play, small group activities are used to explore how understanding can unravel through experience, also shape PBL. There are also parallels to be drawn between PBL and what Korthagen (2008) calls the pedagogy of 'realistic' teacher education. Korthagen argues that the starting point for teacher education should be students' practical experiences and the 'theories' (with a small ' $\mathrm{t}$ ') constructed around them, rather than officially imposed theories (with a capital ' $\mathrm{T}$ ') handed down from teacher educators.

\section{Previous research}

In the UK, there has been very little written about the use of PBL in teacher education (McPhee, 2002: McPhee and Patrick, 2003). Most studies are based in Singapore, Australia, British Columbia, Canada and North America, where the case for adopting PBL in school and teacher preparation contexts has been made by several writers from different perspectives (Dean, 1999; Murray-Harvey \& Slee, 2000; Brush and Saye, 2014; Simone, 2014). These include the argument that American high school and preservice students need to 'experience' subjects in real-world contexts if they are to develop the requisite knowledge and skills to generate economic improvement (Mong and Ertmer, 2013).

Studies in other disciplines suggest that students who follow PBL programmes do as well if not better than traditional learners in retaining knowledge for high-stakes tests, improving problem-solving and collaborations skills, as well developing positive attitudes to learning (Strobel and van Barneveld, 2009; Walker and Leary, 2009). Therefore, our study set out to systematically explore the impact of a PBL approach on student perceptions, engagement and outcomes as they undertook modules as part of their initial teacher education programme.

\section{METHODOLOGY}

\section{Research design}

This study adopted a pragmatic, mixed methods approach to data collection. This was broadly positioned towards the qualitative, interpretative side, but where appropriate we also gathered quantitative data. Johnson and Onwuegbuzie (2004:17) suggest that the 'basic pragmatic maxim in mixed methods research is choose the combination or mixture of methods and procedures that works best for answering your research question. Ethical approval for the research was granted by the University Ethics Committee and consent gained from participating students. The British Educational Research Association's ethical guidelines were adhered to throughout (BERA, 2011). All participants were voluntary and pseudonyms used through the research. 
The case study approach lends itself to examining innovative educational practices (Merriam, 1988) and enabled us to focus on the extent to which the primary participants (i.e. students) considered that PBL supported their development as teachers. The key research question that this paper reports on is the extent to which PBL is perceived to motivate, engage and challenge students.

The questionnaire design and interview questions were adapted from the evaluation toolkit guidance provided by the PBL Special Interest Group of the Higher Education Academy (Marcangelo et al., 2009). This toolkit includes robust guidelines for data collection, derived from a review of existing literature, including steps to ensure the validity and reliability of data. Through our questionnaires and interviews, we ensured content validity by asking questions that focused only on the extent to which students believed that PBL motivated, challenged and engaged them in their studies. Specifically, we included questions about the development of generic skills (e.g. communication and teamwork), dispositions (e.g. listening with empathy) and pedagogy (e.g. responding to behavioural issues or parental concerns).

The focus of the data analysis was on how students perceived PBL, in terms of strengths and challenges. Questionnaires were analysed using an online tool to provide qualitative and quantitative data. Student assignment grades were analysed using Microsoft Excel and videos and interviews with participants were transcribed, coded and analysed to identify key themes. Critical discourse analysis (Barrett and Moore, 2011) provided an appropriate means of analysing the social context of PBL meetings.

\section{Participants and data}

Initially, the whole-cohort of preservice teachers $(\mathrm{n}=$
120 undergraduates and 160 postgraduates) were invited to complete a voluntary, anonymous and confidential online questionnaire. We also selected a random sample of five per cent ( $\mathrm{n}=14)$ of students ( 7 postgraduates and 7 undergraduates) who were asked whether they wished to participate in semi-structured group interviews. These interviews enabled us to investigate in more detail the students' 'lived experience' of PBL through such openended questions as: 'Tell us about whether you have found PBL difficult?' From an ethical viewpoint, we were aware that the students may have felt obliged to take part as we were their tutors, so we took care to ensure that they understood the voluntary nature of the study, and that their comments would remain anonymous and confidential.

As well as students' self-reported behaviours in questionnaires and interviews, we gathered observational data through video-recordings of student PBL group meetings. A total of 14 hours of video footage showing students working in their PBL groups was collected. This video footage typically comprised a clip of a meeting which lasted from fifteen to thirty minutes in which the group discussed scenarios and actions to undertake. Videos were transcribed and analysed to identify themes (see table 1). We followed the advice of Hartas (2010) in creating clear code definitions, keeping a code logbook, avoiding the creation of too many codes and ensuring that there was a distinct purpose for each code.

We analysed the module evaluations that all 280 students completed as part of their studies and reviewed outcomes of students' written assignments. We considered average mark profiles in PBL and non-PBL modules and what this could tell us about student achievement. We also considered the evidence from External Examiner reports. 
Table 1. Codes used to analyse interviews and videorecordings of group meetings

\begin{tabular}{|c|c|}
\hline Code name & Definition \\
\hline DIS & $\begin{array}{l}\text { Dispositions such as persistence, resilience and flexible } \\
\text { thinking }\end{array}$ \\
\hline ATT & Attendance at group meetings and other sessions \\
\hline COM & $\begin{array}{l}\text { Reference to communication skills (reading, writing, } \\
\text { speaking and/or listening) }\end{array}$ \\
\hline TW & $\begin{array}{l}\text { Teamwork skills such as sharing resources, joint planning } \\
\text { and delegation }\end{array}$ \\
\hline RS & $\begin{array}{l}\text { Research skills such as locating, sorting and interpreting } \\
\text { information }\end{array}$ \\
\hline TM & Time management skills \\
\hline CK & Content and/or subject knowledge relating to scenarios \\
\hline PS & Problem-solving skills \\
\hline $\mathrm{SCHL}$ & Applications to school contexts \\
\hline OPV & Recognising Other People's Views \\
\hline RP & Reflective practice including critical thinking \\
\hline $\mathrm{PBL}+$ & Any comments about perceived benefits of PBL \\
\hline PBL- & Any comments about perceived challenges with $\mathrm{PBL}$ \\
\hline
\end{tabular}

\section{RESULTS}

While the lack of control group and the small sample size are limitations to this study, the results and findings show very strong support for PBL among those training to be teachers in our setting. The strengths identified by both undergraduate and postgraduate students were similar (Table 2). This could be attributed to the common teaching team across both programmes.

\section{The benefits of PBL - questionnaire responses}

Numbers are the average of 120 undergraduate and 160 postgraduate students

The results indicate that for both undergraduate and postgraduate students, perceived benefits of PBL are most strongly seen to relate to applying theoretical knowledge to
Table 2. Student perceptions of how PBL supports their training and development

\begin{tabular}{|c|c|c|}
\hline $\begin{array}{l}\text { The following aspects of PBL } \\
\text { helped me to develop as a } \\
\text { teacher }\end{array}$ & $\begin{array}{l}\text { Undergraduate } \\
\text { Mean score } \\
(n=120)\end{array}$ & $\begin{array}{c}\text { Postgraduate } \\
\text { Mean score } \\
(n=160)\end{array}$ \\
\hline $\begin{array}{l}\text { Applying theoretical knowledge } \\
\text { to real-life problems }\end{array}$ & 1.12 & 1.65 \\
\hline $\begin{array}{l}\text { Understanding multiple } \\
\text { viewpoints }\end{array}$ & 1.23 & 1.50 \\
\hline $\begin{array}{l}\text { Questioning information, } \\
\text { assumptions, values and beliefs }\end{array}$ & 1.64 & 1.80 \\
\hline Working alongside peers & 2.40 & 1.80 \\
\hline Communicating clearly & 2.52 & 2.00 \\
\hline $\begin{array}{l}\text { Listening with empathy to } \\
\text { others }\end{array}$ & 2.60 & 2.40 \\
\hline Undertaking research skills & 2.80 & 2.20 \\
\hline \multicolumn{3}{|c|}{$\begin{array}{l}\text { * Responses are on the following scale: } 1 \text { - strongly agree to } \\
>5 \text { - strongly disagree. } \\
\text { Numbers are the average of } 120 \text { undergraduate and } 160 \\
\text { postgraduate students }\end{array}$} \\
\hline
\end{tabular}

real-life problems and understanding multiple viewpoints, with most students strongly agreeing that PBL helped with this. Understanding research skills and listening with empathy were the two aspects that had the highest mean scores, indicating that students did not agree with these so strongly. However, the mean score for both groups indicates that the students did agree that PBL helped these skills develop. No aspect received any 'strongly disagree’ or 'disagree’ responses.

\section{Module mark analysis}

Table 3 results indicate that for postgraduate students, modules containing PBL have higher average marks, and have greater numbers of students receiving distinction grades than non-PBL modules.

Table 3. Module mark analysis for postgraduate programme (n=160)

\begin{tabular}{lccccc}
\hline Module & $\begin{array}{c}\text { Mean } \\
\text { mark }\end{array}$ & $\begin{array}{c}\text { Standard } \\
\text { deviation }\end{array}$ & $\begin{array}{c}\text { Percentage } \\
\text { gaining } \\
\text { Distinction }\end{array}$ & $\begin{array}{c}\text { Percentage } \\
\text { gaining } \\
\text { Merit }\end{array}$ & $\begin{array}{c}\text { Percentage } \\
\text { gaining } \\
\text { Pass }\end{array}$ \\
\hline PBL & $65 \%$ & 7.10 & 18.2 & 58 & 23.8 \\
\hline Curriculum & $60 \%$ & 7.68 & 6.9 & 30.3 & 62.8 \\
\hline Pedagogy & $62 \%$ & 10.11 & 13.3 & 30.7 & 56.0 \\
\hline
\end{tabular}


Table 4 results indicate that for undergraduate students, modules with PBL elements do not have the highest marks awarded when compared to non-PBL modules. However, PBL modules have a smaller standard deviation of marks, and a higher average mark than non-PBL modules.

Table 4. Module mark analysis for final year undergraduate programme $(n=120)$

\begin{tabular}{lcccc}
\hline Module & $\begin{array}{c}\text { Highest mark } \\
\text { awarded }\end{array}$ & $\begin{array}{c}\text { Lowest mark } \\
\text { awarded }\end{array}$ & $\begin{array}{c}\text { Mean mark } \\
\text { awarded }\end{array}$ & $\begin{array}{c}\text { Standard } \\
\text { Deviation }\end{array}$ \\
\hline PBL & $68 \%$ & $51 \%$ & $59.6 \%$ & 4.01 \\
\hline Curriculum & $71 \%$ & $44 \%$ & $57.3 \%$ & 6.71 \\
\hline Pedagogy & $72 \%$ & $40 \%$ & $58.8 \%$ & 9.11 \\
\hline
\end{tabular}

\section{Perceived challenges of PBL - questionnaire responses}

Table 5 shows that undergraduate students report the greatest challenge of PBL to be related to time management, whilst the postgraduates report that the greatest challenge is to do with lack of tutor guidance.

Table 5. Student perceptions on the greatest challenges raised by $\mathrm{PBL}$

\begin{tabular}{lcc}
\hline $\begin{array}{l}\text { The following aspects of PBL } \\
\text { were very challenging: }\end{array}$ & $\begin{array}{c}\text { Undergraduate } \\
\text { Mean score } \\
(\mathbf{n = 1 2 0 )}\end{array}$ & $\begin{array}{c}\text { Postgraduate } \\
\text { Mean score } \\
(\mathbf{n}=\mathbf{1 6 0})\end{array}$ \\
\hline Time management & 1.20 & 1.50 \\
\hline Lack of tutor guidance & 1.50 & 1.30 \\
\hline $\begin{array}{l}\text { Finding information on the } \\
\text { topic }\end{array}$ & 1.75 & 2.20 \\
\hline Group work & 1.64 & 1.80 \\
\hline * Responses are on the following scale: $1-$ strongly agree to \\
$>5$ - strongly disagree. Nu
\end{tabular}

\section{Analysis of video}

Table 6 indicates the number of times students commented in relation to these themes during videos of group work or interviews. Comments relating to school contexts, communication skills, other people's viewpoints and perceived benefits of PBL were reported most frequently. Comments relating to research skills were made least commonly.

Table 6. Analysis of video and interviews

\begin{tabular}{|c|c|c|}
\hline Code & Definition & Count \\
\hline DIS & $\begin{array}{l}\text { Dispositions such as persistence, resilience and } \\
\text { flexible thinking }\end{array}$ & 22 \\
\hline ATT & Attendance at group meetings and other sessions & 26 \\
\hline COM & $\begin{array}{l}\text { Reference to communication skills (reading, writing, } \\
\text { speaking and/or listening) }\end{array}$ & 32 \\
\hline TW & $\begin{array}{l}\text { Teamwork skills such as sharing resources, joint } \\
\text { planning and delegation }\end{array}$ & 26 \\
\hline RS & $\begin{array}{l}\text { Research skills such as locating, sorting and } \\
\text { interpreting information }\end{array}$ & 6 \\
\hline $\mathrm{TM}$ & Time management skills & 28 \\
\hline CK & $\begin{array}{l}\text { Content and/or subject knowledge relating to } \\
\text { scenarios }\end{array}$ & 36 \\
\hline PS & Problem-solving skills & 27 \\
\hline $\mathrm{SCHL}$ & Applications to school contexts & 40 \\
\hline OPV & Recognising Other People's Views & 35 \\
\hline $\mathrm{RP}$ & Reflective practice including critical thinking & 18 \\
\hline $\mathrm{PBL}+$ & Any comments about perceived benefits of PBL & 44 \\
\hline PBL- & Any comments about perceived challenges with $\mathrm{PBL}$ & 21 \\
\hline
\end{tabular}

\section{FINDINGS}

These results indicate that both postgraduate and undergraduate students agree over the ways in which PBL helps them to develop a range of professional skills. In particular, students value opportunities to see how knowledge can be applied in order to solve problems in real-life contexts. They also appreciate how PBL helps them to make sense of complex situations in school. There were no statistical differences in the responses of male and female students among either undergraduate postgraduate students.

\section{The main strengths of PBL}

One of the major advantages of PBL is that for most students it is intrinsically motivating, which research suggests is more effective than external motives (Cerasoli 
et al., 2014). Both the case study survey data and student interviews convey an overwhelmingly positive message. On average, $90 \%$ of participants were strongly in agreement that they feel very motivated and engaged by PBL, more so than traditional approaches, where only between $50-60 \%$ strongly agreed that lectures, for instance, were motivating and engaging. When asked to explain the difference, most students said that PBL sessions offered 'more opportunities to participate, were 'less boring' than lectures, and were 'more flexible' in where, when and what was discussed: 'I liked the fact that we could meet in the quad (café), library or online and discuss in an informal manner what we had researched.' The fact that students found PBL more engaging than traditional approaches, cannot be explained in terms of different tutors because modules are delivered by the same team.

We found that the authentic nature of PBL engages students as prospective teachers. It is widely seen to promote skills that teachers need, particularly problemsolving, teamwork and communication skills. 'Relevance' was the most frequently cited word in the participants' positive reviews of PBL and explains why they find it motivating and engaging. Schools are complex places, which demand that those entering the profession should to be knowledgeable enough to handle appropriately the unexpected as well as the familiar. So, teachers need to be flexible thinkers, possess the skills to communicate clearly and sensitively and demonstrate critical insight. Our findings show that PBL can support teacher educators in developing these skills and dispositions. Almost all 1st-year students (98\%) recognise that engaging in a PBL scenario 'really helps them think'. In particular, there was a strong consensus that the power of PBL lies in making them more thoughtful teachers. As one Year 2 student put it: 'PBL has helped me to look at things from a different perspective and not to make knee-jerk judgments'.
One of the goals of PBL is to promote transferable skills, such as effective collaboration (Hmelo-Silver, 2004), and the data indicates that students realize this. As one Jo, a Year 2 student, explained: 'It is beneficial to work with others, as it gears us up for our professional careers.' Most of the student responses indicate that they had learned to do things which they had not automatically associated with teaching, such as planning staff meetings with an agenda, undertaking group tasks to deadlines and responding to colleagues who had not fulfilled their tasks. One undergraduate described these as 'background skills' while another pointed out that 'there is so much said in teaching about the importance of interpersonal skills PBL actually allows you to demonstrate these in practice in the university, almost as a rehearsal before you set foot in school.' Underpinning much of this learning was a recognition that professional trust matters.

We have argued elsewhere that PBL fosters the dispositions or what Costa and Kallick (2000) call 'habits of mind' that teachers need (Author and author, 2012). Students in their reflective diaries for this case study reiterate this. They refer to persistence in seeking to 'uncover' the stories behind the scenarios, striving for accuracy in identifying precisely what is known about incidents, thinking interdependently in drawing upon each other's thoughts and questioning and problem solving. As one student put it: 'Habits of mind run through PBL. You have to define terms, probe what's going on, check out what others say and come up with plausible suggestions.'

Building on previous research (Clouster, 2007; Azer, 2009), our fine-grain analysis of video-recorded PBL group meetings to date has shown that the most successful interactions share common characteristics: the discussions have purpose, often established through an agreed agenda and a commitment to following this. There is trust among 
participants to carry out assigned tasks and flexibility when things do not work out as planned - for example, if a group member fails to complete an assignment. When students disagree in their interpretation of problems, they recognize that this is not necessarily a weakness but reflects the nature of PBL. In short, they can handle uncertainty as part of the learning process. These issues have practical implications for universities as well as schools, where the value of group work and collaborative enquiry continues to engage debate (e.g. Baines et al., 2015). We are particularly interested in the extent to which PBL strategies in preservice teacher education can be transferred to school contexts.

\section{PBL and its challenges}

In the early days, we found that there were misconceptions over what PBL meant to students (and tutors), and how it was approached, with some seeing it as the same as 'problem solving', 'directed study' and 'independent learning. This highlighted the need for a consistent understanding of terminology and approach, which was achieved through regular staff discussions, sharing of exemplary practice, peer monitoring with feedback, directed reading and uploading guidance on the university intranet (e.g. in the form of 'frequently asked questions'). In more recent times, module leaders have produced short podcasts that explain the assessment criteria and expectations.

Undergraduate and postgraduate students generally agreed over the main challenges associated with PBL. The main difference between the groups related to the difficulties some undergraduates, fresh from high school, found in completing self-directed research tasks. Many first-year students comment upon how different PBL is compared to their own school experiences and a few find the adjustment from listening and taking notes in lectures to more proactive and collaborative responsibilities daunting. As Savin-Baden and Howell (2004: 81) put it, 'traditional paths of success have been changed: students know how to win the old game, but the new game has new rules.' Some students found selfdirected learning challenging, particularly setting goals, monitoring progress, planning ahead, and motivating the self and others. Cunnane (2011) cites research suggesting that 1 in 3 first-year undergraduates struggle at, and are 'puzzled' by, independent learning because this goes against their previous school experiences. Having said this, no respondents considered that PBL was an inappropriate form of learning at university although there were occasional comments about wanting 'more lectures'. This is despite evidence that lecturing is not the most effective means of instruction (Gibbs, 2013).

In their free text responses to questionnaires and during semi-structured interviews and video reflections, analysis revealed that students faced challenges when working collaboratively. Group dynamics are an important factor in the success or otherwise of PBL. On the one hand, in our experience peer pressure to meet deadlines and contribute to collective responsibilities can motivate even the most recalcitrant of students: 'I could always hide the lecture hall' whereas I felt I had to say something in a small group peer pressure was greater!' However, inevitably personality clashes arise. One of the key messages for PBL leaders is deciding how to organise groups (e.g. self-selected or based on student subject or phase interests) and what actions to take if relationships break down. We adopt a self-reporting system in which students can confidentially discuss pastoral and academic issues with module leads. At the outset of every PBL module, expectations are made clear about individual and collective responsibilities, for example in negotiating group ground rules and what actions can be taken to resolve difficulties - the very raison 
dêtre of PBL.

PBL is a demanding process, even for those students who achieve high academic standards in traditional modules. Here is the reflection made by Beth, a final year student:

Personally I found PBL quite challenging especially in a group situation where we had to discuss a situation together. Because I am passionate and always strive for excellence, I can be quite controlling and this can be a negative to our group. I've really had to think about my own practice... am I thinking flexibly? Am I working well in a team? Or am I overcompensating for a perceived lack of...umm, perhaps I perceive that other members of the group are weaker than I am... and that they have nothing to contribute and this has been a hard thing for me to think about myself because I don't want to judge others. I want to work as a team as this is an important attribute for my future career.

Even though Beth and her other group members addressed their particular task very well and gained high marks in the module, participating in PBL prompted her to think about her own personal development in relation to her future career.

The focus for this study has been on the views of students. However, their responses raise questions about the challenges facing tutors as they seek to implement effective approaches to the curriculum. These include the shifting role of the tutor, supporting self-directed learning and confronting resource requirements (Poikela and Moore, 2011; Little and McMillan, 2016). We have also found further challenges in the design of non-contrived scenarios and finding space in a crowded curriculum. This has meant that convincing colleagues of the value of PBL was a priority. Comments from external examiners and students, along with demonstrable student competences, were the most persuasive factors. One external examiner commented that PBL modules were innovative, interesting and enabled students to gain the skills they need to become excellent practitioners'.

What is clear is that senior leaders need to develop a culture in which both colleagues and students 'buy into' the PBL approach. Our responses show that this is not straightforward, particularly for experienced staff that may question the transition from lecturer to facilitator or 'cognitive coach' (Filipenki and Naslund, 2016). Noticeably, this instructional shift was not so much of a challenge for those teacher educators grounded in early years' practice, familiar with child-centred pedagogies and the adult's facilitating role.

\section{Analysis of module marks}

An analysis of module marks in Tables 3 and 4 show that overall undergraduate and postgraduate students achieved higher grades in PBL-led modules than they did in other modules, particularly in terms of the highest 'merit' or 'distinction' levels, and the standard deviation is lowest. For undergraduates, although higher marks were gained in other modules, the mean mark awarded is highest for PBL modules, and the standard deviation is lowest. All assignments are assessed against four broad criteria (subject knowledge and understanding; intellectual skills; pedagogical and professional applications: and transferable skills). Modules are marked, standardised and moderated by the same team of tutors.

These results may reflect differences in the types of module assessments, the individual cohort or the timing in the year - for example, the postgraduate PBLled module is the final one to be submitted in the year. Hence module marks do not necessarily provide a reliable 
dataset upon which to judge the effectiveness of PBL. We acknowledge that there is a need to look at trends in data over time. However, the marks provide a useful indication that the PBL approach is successful and our initial mark analysis supports student perceptions. In discussions with undergraduate students in Years 2 and 3, we found that many knew their marks were generally higher in PBLled modules than others. They attributed this to their enjoyment of and responsiveness to the scenario tasks, rather than less challenging assessment.

\section{CONCLUSIONS}

Our focus then on the perceived merits and challenges of PBL suggest that, on balance, greater consideration across the sector should be given to the use of Problembased Learning, which inspectors observed as a good feature during their visit to the South West Wales Centre of Teacher Education (Estyn, 2012). Four years on, our further analysis shows how PBL supports pre-service teachers in their training and development. It represents the first published study of PBL in teacher education in Wales and one of the few in the UK.

Despite the challenges raised in this paper, our findings indicate that PBL has significant potential in the field of teacher education. Student perceptions of the PBL experience were positive. PBL offers a bridge between theory and practice and supports 'how' as well as the where' and 'what' programmes of ITET need to deliver. In the words of one newly-qualified teacher, looking back on his PBL experiences in university, 'I didn't realize at the time how well PBL prepared me for teaching. For example, when we looked at school data I could really hold my own in staff discussions even among those colleagues who have been teaching for many years.' For teacher educators and policy makers, the main implication from this paper is that much greater focus needs to be put on the methodologies and models offered by tutors and mentors. What is missing from current debate over the future of teacher education in Wales and elsewhere is how effective teacher educators engage students. This is significant at a time when student engagement in higher education is a pressing concern (Trowler, 2010).

In our experience, the success or otherwise of $\mathrm{PBL}$ depends upon three things: the scenario design; the quality of group interactions; and the commitment of tutors and senior leaders. Our findings point to the importance of designing PBL scenarios to catch and sustain student interest. For instance, by releasing the scenario in stages with potential twists and turns (e.g. offering contradictory sources each week), reference to popular culture, moral dilemmas and controversial issues. We found that the most engaging problems shared common characteristics: they drew upon a range of sources, reflected current school practices, had a humorous element, stimulated debate, offered no simple solution, operated at multiple levels, and required further research. Effective teamwork is dependent on many factors, including building common purpose, how conflict is managed, clarity over roles and sound team leadership.

In summary, this research has advanced our understanding of the strengths associated with PBL as a teaching approach in teacher education. It supports findings from other disciplines in terms of student motivation and engagement. PBL is perceived by preservice teachers to offer them a safe environment to practise dealing with complex, messy scenarios and fosters the collaborative skills increasingly recognised as essential in the workplace (World Economic Forum, 2016). Within the limitations of our small-scale study, the data also 
indicates that PBL enabled students to achieve higher grades comparative to non-PBL modules. This research has also shown that PBL enables teacher educators to reflect on their own teaching styles and their expectations of students. In the words of one tutor, 'I was a bit cynical at the start, but found that PBL offers a genuine opportunity to learn together'.

\section{ACKNOWLEDGEMENT}

The authors would like to thank Professor Chris Taylor and Professor Sally Power at Wiserd Education for initial support in developing this article.

\section{REFERENCES}

Azer, S.A. (2009). Interactions between students and tutor in problem-based learning: the significance of deep learning. The Kaohsiung Journal of Medical Sciences, 25 (5), 240-249.

Baines, E., Blatchford, P., \& Webster, R. (2015) The challenges of implementing group work in primary school classrooms and including pupils with special educational needs. Education 3-13: International Journal of Primary, Elementary and Early Years Education, 43 (1), 15-29.

Barrett, T. (2004c). 'Researching the dialogue of PBL tutorials: a critical discourse analysis approach'. In M. Savin-Baden and K. Wilkie (Eds.), Challenging Research into Problem-based learning. Buckingham: Open University Press.

Barrett, P. (2010). The problem-based learning process as finding and being in flow, Innovations in Education and Teaching International, 47(2), May 2010, 165-174.

Biggs, J. \& Tang, C. (2007). Teaching for Quality Learning at
University, Maidenhead: Open University Press.

British Educational Research Guidelines (2011). Ethical Guidelines for Educational Research, London: BERA.

Brush, T. \& Saye, J. (2014). Guest Editors' Introduction: Special Issue on Technology-Supported Problembased Learning in Teacher Education. Interdisciplinary Journal of Problem-Based Learning, 8 (1).

Caena, F. (2014) European Commission. Initial teacher education in Europe: an overview of policy issues, Brussels: European Commission.

Carter, A. (2015). Carter review of initial teacher training (ITT), London: DfE.

Clouston, T. (2007). Exploring methods of analysing talking in problem-based learning tutorials. Journal of Further and Higher Education, 31 (2), 183-193.

Costa, A. and Kallick, B. (2000). Activating and Engaging Habits of Mind, Alexandria, VA: ASCD.

Cunnane, S. (2011). 'To spoon-feed is not to nurture', Times Higher Education, 24 November 2011.

Darling-Hammond, L. \& Rothman, R. (2011). (Eds.) Teacher and Leader Effectiveness in High Performing Systems. CA: Stanford Center for Opportunity Policy in Education.

Dean, C. (1999). Problem Based Learning in Teacher Education. Paper presented at the American Education Research Association Annual Meeting. Montreal, April 19-23.

Murray-Harvey, R., \& Slee, P. (2000). Problem Based Learning in teacher education: Just the beginning!' Paper presented at Australian Association for Research in Education. Sydney, December 4-6.

Department for Employment and Learning (2014). Aspiring to Excellence Final Report of the International Review Panel on the Structure of Initial Teacher Education in Northern Ireland, Belfast: DEL.

Donaldson, G. (2011). Teaching Scotland's Future, Edinburgh: The Scottish Government. Estyn (2012). A 
report on South West Wales Centre for Teacher Education and Training, Cardiff: Estyn

Estyn (2015a). A report on North and Mid Wales Centre for Teacher Education and Training, Cardiff: Estyn

Estyn (2015b). Estyn Writing Guide, Cardiff: Estyn.

European Commission (2013). Supporting teacher competence development for better learning outcomes. Brussels: European Commission.

Furlong, J. (2015). Teaching Tomorrow's Teachers; options for the future of initial teacher education in Wales. Cardiff: Welsh Government.

Furlong, J. (2016). 'Initial Teacher Education in Wales - a Rationale for Reform' Wales Journal of Education, 18.1, 45-63.

Gibbs, G. (2013). 'Lectures don't work but we keep using them', The Times Higher Education, 21 November 2013.

Grigg, R. \& Lewis, H.E. (2012). 'Developing Dispositions to Learn: Using Problem-Based Learning Scenarios to Promote Effective Habits of Mind in Students', Paper presented at the 16th International Conference on Thinking, Wellington, New Zealand.

Harré, R. (2012). Positioning theory: moral dimensions of social-cultural psychology. In J. Valsiner (ed.) The Oxford Handbook of Culture and Psychology. New York: Oxford University, 191-206.

Hartas, D. (2010) Educational research and inquiry: qualitative and quantitative approaches. London: Continuum International Publishing Group.

Hattie, J. (2013) Teachers make a difference - what is the research evidence? Professional Learning and Leadership Development, New South Wales: Department of Education and Training.

Henderson, R. (2016) (Ed.) Problem-based Learning: Perspectives, Methods \& Challenges, Nova Science Publishers Inc.

Hmelo-Silver, C. (2004). Problem-based learning: What and how do students learn? Education Psychology
Review, 16(3), 235-266.

Johnson, R.B. \& Onwuegbuzie, A.J. (2004) 'Mixed Methods Research: A Research Paradigm Whose Time Has Comé, Educational Researcher, Vol. 33, No. 7 (Oct., 2004), 14-26.

Korthagen, F.A. (2008). Linking Practice and Theory, London: Routledge.

Little, P. \& McMillan, M. (2016) 'Determining the sustainability of a model of PBL: A Conceptual framework', Journal of Problem-Based Learning, 2016 (3), $1-8$.

Marcangelo, C., Gibbon, C., \& Cage, M. (2009). Problembased Learning Evaluation Toolkit, HEA.

Mezirow, (1981). 'A Critical Theory of Adult Learning and Education' Adult Education Quarterly September 1981, 32: 3-24.

McPhee, A. (2002). 'Problem Based Learning in initial teacher education: taking the agenda forward', in Journal of Educational Enquiry, 3(1), 60 - 78.

McPhee, A.D \& Patrick, F. (2003). 'Problem based learning in a postgraduate course of initial teacher education', European Conference on Educational Research, Hamburg, Germany.

Merriam, S.B. (1988). Case study research in education: a qualitative approach, San Francisco: Jossey-Bass.

Mong, C. J. \& Ertmer, P. A. (2013). 'Addressing STEM Education Needs: The Case for Adopting a PBL Approach, Educational Technology, v53(3), n3 p12-21 May-Jun 2013.

OECD (2010). Strong Performers and Successful Reformers in Education: Lessons from PISA for the United States. Paris: OECD Publishing.

Poikela, S. \& Moore, I. (2011). 'PBL Challenges Both Curriculum and Teaching. In T. Barrett, and S. Moore (2011) (Eds.) New Approaches to Problem-Based Learning, New York: Routledge, 229-251. 
QAA (2015). Subject Benchmark Statement UK Quality Code for Higher Education. Part A: Setting and maintaining academic standards. Education Studies, Glocuester: QAA.

Savin-Baden, M. (2000). Problem-based learning in higher education: Untold stories. Buckingham: Open University Press.

Schwartz, P, Mennin, S, Webb, (2001). G Problem-based learning: case studies, experiences and Practice, London: Routledge.

Simone, C.D. (2014). 'Problem-Based Learning in Teacher Education: Trajectories of Change', in International Journal of Humanities and Social Science, Vol 4(12), October 2014, 17-29.

Strobel, J., \& van Barneveld, A. (2009). 'When is PBL more effective? A meta-synthesis of meta-analyses comparing PBL to conventional classrooms' The Interdisciplinary Journal of Problem-Based Learning, 3(1), 44-58.

Tabberer, R. (2013). A Review of Initial Teacher Training in Wales. Cardiff: Welsh Government.

Tipping, J., Freeman, R.F. \& Rachlis, A.R. (1995). Using faculty and student perceptions of droup-dynamics to develop recommendations for PBL training. Academic Medicine, 70 (11), 1050-1052.

Trowler, V. (2010). Student engagement literature review, London: HEA.

Universities UK (2014). Higher education in focus, London: Universities UK.

Walker, A. \& Leary, H. (2009). 'A problem-based learning meta analysis: Differences across problem types, implementation types, disciplines, and assessment levels', Interdisciplinary Journal of Problem-based Learning, 3(1), 12-43.

White, S. \& Featherstone, B. (2005). Communication misunderstandings: Multi-agency work as social work practice, Child and Family Social Work, 10(3), 207-16. World Economic Forum (2016) New Vision for Education: Fostering Social and Emotional Learning through Technology, World Economic Forum. 
